\title{
IEDZĪVOTĀJU SASTĀVS UN MIGRĀCIJAS IEZİMES RĪGAS AGLOMERĀCIJĀ
}

\author{
Jānis Krūmiņš \\ Latvijas Universitāte, G̣eogrāfijas un Zemes zinātṇu fakultāte, e-pasts: \\ kruminsjanis3@gmail.com
}

\begin{abstract}
Anotācija. Pētījuma mērḳis ir novērtēt demogrāfisko pazīmju nozīmi migrācijas rakstura veidošanā Rīgas aglomerācijas iedzīvotājos. Tādējādi abu šo zonu migrācijā iesaistītie un neiesaistītie (mobilie - nemobilie) iedz̄ivotāji tiek salīdzināti pēc dažādiem demogrāfiskiem raksturlielumiem (piem., dzimums, vecums, etniskā piederība), lai skaidrotu saikni starp iekšzemes migrāciju un iedzīvotāju sastāva attīstību dažādās Rīgas ietekmes zonās. Pētījumā izmantoti 2011. gada Tautas skait̄̌šanas dati par iedzīvotājiem, kas dzīvo Rīgas aglomerācijā ietilpstošajās pašvaldībās. Pētījuma rezultāti parāda, ka augstāka varbūtība iesaistīties iekšzemes migrācijā ir 1) vīriešiem, 2) gados jauniem iedzīvotājiem, 3) latviešiem un 4) iedzīvotājiem ar augstāko izglītību.
\end{abstract}

Atslēgas vārdi: iekšzemes migrācija, ǵeogrāfiskā mobilitāte, iedzīvotāju sastāvs, Rīgas aglomerācija.

\section{Ievads}

Latvijā, līdzīgi kā citās postsociālistiskajās valstīs Centrāleiropā un Austrumeiropā, suburbanizācijas ietekmē vērojama lielpilsētu aglomerāciju izplešanās (Tammaru et al. 2004; Ouredniček 2007; Krišjāne, Bērziṇš 2012 u.c.). Iepriekšējo pētījumu rezultāti liecina par intensīvu piepilsētas apdzīvojuma attīstību Rīgas aglomerācijā un ar to saistîtajām pārmaiņām iedzīvotāju sastāvā un mobilitātes intensitātē (Bērziņš, Krišjāne 2008; Bērziņš 2011a). Mazāk ir pētîta migrācijas procesu loma iedzīvotāju sastāva veidošanā (Bērziņš 2011b; Krišjāne et al. 2012; Burgmanis 2014). Tāpēc nepieciešami pētījumi par suburbanizācijas procesu ietekmē notikušajām iedzīvotāju sastāva pārmaiṇām Rīgas aglomerācijā, īpašu uzmanību pievēršot dažādiem galvaspilsētas ietekmes areāliem - aglomerācijas iekšējai un ārējai zonai. Šis aspekts ir maz pētīts gan piepilsētas apdzīvojuma attīstības, gan iedzīvotāju geogrāfiskās mobilitātes kontekstā.

Latvijas teritorijai raksturīgās starpreǵionu migrācijas plūsmas ir vērstas no valsts perifērijas uz tās centrālo daḷu - galvaspilsētu un tās ietekmes areālu - Rīgas aglomerāciju. Savukārt aglomerācijas mērogā izteikti dominē ar Rīgu saistītās migrācijas plūsmas, kas vērstas uz piepilsētu. Rīgas aglomerācija nav administratīvi noteikta teritoriāla vienība, bet gan funkcionāls areāls, kā robežas un iekšêjā struktūra var mainīties. Šajā pētījumā ņemtas vērā aglomerācijas robežas, kas tika precizētas 2012. gadā, kad tās platība bija $7297,6 \mathrm{~km}^{2}$ jeb $\sim 11 \%$ no valsts kopplatības (RD PAD 2012). Tajā pašā laikā aglomerācijas pašvaldībās dzīvoja nedaudz vairāk par pusi no visiem Latvijas iedzīvotājiem (Tautas skaitīšana 2011), kas norāda uz teritorijai raksturīgo visai augsto apdzīvojuma blīvumu, kā arī ražošanas un pakalpojumu koncentrāciju.

Rīgas aglomerāciju kopumā raksturo augstāki ekonomiskie un sociāli demogrāfiskie rādītāji, salīdzinot ar pārējo valsts teritoriju. Tomēr aglomerācijas teritorija nav viendabīga un to veido trīs atšķirīgas daḷas - Rīgas pilsēta (kodols), iekšējā un ārējā zona. Tieši aglomerācijas zonu izpētei līdz šim ir pievērsta visai maza 
uzmanība, lai gan starp tām pastāv noteiktas atškirīibas. Piemēram, laika periodā no 2000. līdz 2017. gadam iedzīvotāju skaits iekšējā zonā palielinājies par $\sim 12 \%$, kamēr ārējā zona piedzìvojusi $\sim 15 \%$ samazinājumu (CSP 2018). Tāpat atšķirīgas ir arī iedzīvotāju ienākuma nodokḷa vērtības, kas nonāk pašvald̄̄bu budžetos. 2016. gadā iekšējās zonas pašvaldību budžetos tika ieturēti 780 eiro uz 1 iedzīvotāju, kamēr ārējā zonā - par 230 eiro mazāk (RAIM 2017). Tas ietekmē apdzīvojuma un ekonomiskās attīstības, kā arī iedzīvotāju migrācijas un sociāli demogrāfiskā sastāva atšḳirības abās zonās. Līdz šim suburbanizācijas procesi vairāk ietekmējuši aglomerācijas iekšējās zonas attīstību un mazāk izpaudušies āê̄jā zonā. Tā rezultātā vērojamas ne tikai aglomerācijas zonu funkcionāli telpiskās struktūras atšķirības, bet arī pārmaiṇas iedzīvotāju ǵeogrāfiskajā mobilitātē un sastāvā.

\section{Materiāli un metodes}

Iedzīvotāju sastāva un mobilitātes rakstura izpētei izmantoti anonimizēti individuālie 2011. gada tautas skaitǐšanas dati par Rīgas aglomerācijas iekšējās un ārējās zonas pašvaldībās 2011. gada 1. martā deklarētajiem iedzīvotājiem, kuri tika klasificēti 2 grupās - 1) dzīvesvietu mainījušajos (mobilajos) un 2) dzīvesvietu nemainījušajos. Pirmā grupa reprezentē iedzīvotājus, kas dzīvesvietu mainījuši laika periodā no 2010. gada 1. marta līdz 2011. gada 1. martam, kamēr otrā grupa parāda tos, kuri norādītā gada laikā nav pārcēlušies uz citu administratīvi teritoriālo vienību. Kopumā, dzīvesvietu gada laikā mainījuši vien nedaudz vairāk kā $2 \%$ jeb 8954 iedzīvotāji no aglomerācijas zonās dzīvojošo kopskaita, kas ir visai zems rādītājs, bet daḷēji izskaidrojams ar ekonomiskās krīzes apstākḷos sarūkošo iedzīvotāju iekšzemes migrāciju.

Lai raksturotu iekšzemes migrācijā un svārstmigrācijā iesaistīto Rīgas aglomerācijas zonu iedzīvotāju sastāvu, nosakot iedzīvotāju grupas ar augstāku varbūtîbu iesaistīties mobilitātē, pētījumā izmantota binārās logaritmiskās regresijas metode. Binārās logaritmiskās regresijas modelis ir datu analīzes tehnika, kur atkarīgais main̄̄gais ir binārs, pieņemot vērtību 1 vai 0 . Salīdzinot divus mainīgos un piešķirot vērtību $1(\mathrm{Y}=1)$ tiem iedzīvotājiem, kuriem raksturīga, piemēram, augstākā izglīì̄iba. Tikmēr nulles vērtība $(Y=0)$ tiek pieškirta tiem, kuri šai grupai nekvalificēsies vai tādiem respondentiem, kam ir cita veida izglîtīibas līmenis. Rezultātā izveidotā neatkarīgo pazīmju kopa raksturo dzīvesvietu mainījušo un nemainījušo iedzīvotāju demogrāfisko sastāvu.

\section{Rezultāti un interpretācija}

Analizējot Rīgas aglomerācijas zonu iedzīvotāju sastāvu pēc demogrāfiskajām pazīmēm, redzams, ka pastāv būtiskas atškirības starp migrācijā iesaistîto un neiesaistīto iedzīvotāju dzimuma, vecuma, etniskās piederības, ǵimenes statusa un izglīî̉bas līmeṇa rādītājiem. Līdz ar to visas šìs demogrāfiskās pazīmes uzskatāmas par būtiskām iedzīvotāju sastāva veidošanā un attīstībā. Interesanti, ka, piemēram, dažādi ekonomiskie rādītāji (piem., ekonomiskās darbības sektors, piederība kādai no sociāli 
ekonomiskajām kategorijām) neuzrādīja statistiski būtiskas atškirības starp abu grupu iedzīvotājiem. Uz demogrāfisko raksturlielumu nozīmīgumu norādīja līdzīgs pētījums par migrāciju Latvijā un arī aglomerācijas teritorijā (Bērziņš 2011a), kur dzīvesvietu mainījušo grupa pārstāvēja migrantus ilgākā laika posmā.

Iedzīvotāji vecumā no 15 līdz 24 gadiem ir vairāk tendēti uz pastāvīgo iekšzemes migrāciju nekā iedzīvotāji vecumā no 35 līdz 64 gadiem (1. attēls B). Tomēr šī grupa nav uzskatāma par mobilāko, jo tās pārstāvjiem ir mazāka varbūtîba iesaistîties migrācijā nekā 25-34 gadus veciem iedzīvotājiem. To var skaidrot ar faktu, ka šai vecuma grupai raksturīgāks augstāks vidējās izglītības līmenis nekā 15-24 gadus veciem. Aglomerācijas zonās attiecīgi $25,9 \%$ no visiem iedzīvotājiem ar augstāko izglītîbu, ir 25-34 gadus veci, kamēr jaunāko darbspējas vecuma grupu pārstāv 5,1\% ar šādu izglītības līmeni. Tāpat starp otrās vecuma grupas pārstāvjiem raksturīgs lielāks augstākās sociāli ekonomiskās kategorijas pārstāvju īpatsvars $(24,8 \%$ pret $9,1 \%)$. Šos rādīiājus iespējams skaidrot ar tradicionālajiem migrācijas motīviem. Šajā gadījumā mobilitātes plūsmu rakstura veidošanā uz piepilsētām kā galvenie motīvi darbojas mājokḷa apstākḷi un pievilcīgāka vide, bet uz pilsētām - darba un izglītības iespējas. Tieši iedz̄ivotāju grupa vecumā no 25 līdz 34 gadiem ir ekonomiski stabilākā un vienlaikus mobilākā suburbanizācijas procesa gaitā, pārceḷoties uz aglomerācijas pašvaldībām no pilsētām.

Salīdzinot iedzīvotāju sastāvu pēc to etniskās piederības, latviešiem ir lielāka varbūtība iesaistîties mobilitātē, nekā Rīgas aglomerācijas zonu mazākumtautībām (1. attēls C). Šeit jāmin, ka migrācijas veicināšanā nozīmīgu lomu spēlē citu tautiešu klātbūtne teritorijā. Respektīvi, lielāka mazākumtautību mobilitātes intensitāte raksturīga teritorijām, kur ir lielāks mazākumtautību īpatsvars. Iepriekšēji migrācijas pētījumi pierāda, ka atšķiras iedzīvotāju mobilitāte pēc etniskās piederības reǵionālā un starptautiskā līmenī. Pirmajā gadījumā mazākumtautību iedzīvotājiem būs mazāka varbūtîba iesaistīities mobilitātē uz teritorijām, kurās ir lielāks pamatnācijas iedzīvotāju īpatsvars (Tammaru et al. 2011), bet starptautiskās migrācijas gadījumā, mazākumtautību pārstāvji būs vairāk tendēti doties prom no teritorijām, kurās dominē pamatnācija (Ivlevs 2013).

Ja salīdzina dzīvesvietu mainījušos un nemainījušos iedzīvotājus pēc ğimenes statusa, redzams, ka lielāka varbūtība iesaistīties pastāvīgās migrācijas procesā ir tiem iedzīvotājiem, kas nav precēti (ieskaitot šḳīušos iedzīvotājus un atraitṇus (-es)). Neprecētiem iedzīvotājiem bez ǵimenes tradicionāli ir vieglāk mainīt dzīvesvietu un sākt dz̄ivi citā vietā, kamēr precētos iedzīvotājus ar viṇu dzīvesvietu saista ne tikai pašu, bet arī visu ǵimenes locekḷu darba, izglīî̄bas u.c. saites. Izṇēmums ir migrācija no Rīgas uz tuvējo piepilsētas teritoriju, saglabājot darbavietu vai nemainot mācību iestādi. Tādējādi, kā norāda arī iepriekšējais pētījums par suburbanizāciju (Bērziņš 2011a), viena no raksturīgākajām iedzīvotāju grupām dzīvei piepilsētā ir giimenes ar bērniem. Salīdzinot Tautas skaitīšanas datus, redzams, ka vairāk neprecēto migrantu ir starp tiem, kas ieradušies no citiem reǵioniem nevis no Rīgas, respektīvi, 53\% pret 48,5\%, norādot uz pastiprinātu ǵimeṇu migrāciju no Rīgas uz piepilsētu. 

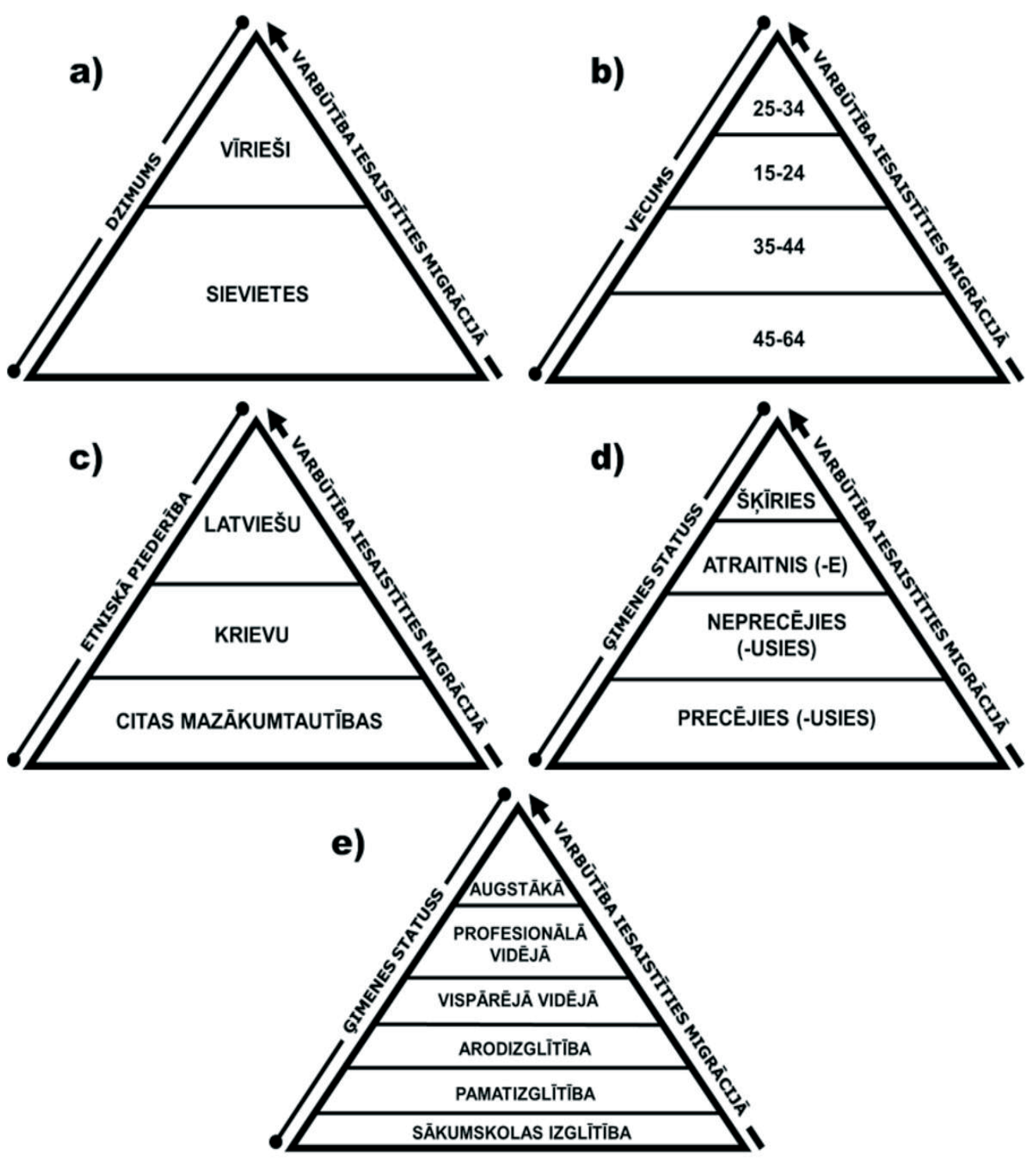

1. attēls. Rīgas aglomerācijas iekšējās un ārējās zonas iedzīvotāju varbūtība iesaistīties iekšzemes migrācijā. Demogrāfiskās pazīmes (izveidojis autors, izmantojot Tautas skaitīšanas datus)

Arī izglìtības līmenis ir viens no demogrāfiskajiem rādītājiem, kas ietekmē migrācijas raksturu Rīgas aglomerācijas iekšējā un ārējā zonā. Lielāka varbūtība iesaistīties migrācijā ir iedzīvotājiem ar augstāku izglītību (1. attēls E), ko iespējams skaidrot gan ar suburbanizācijai raksturīgā iedzīvotāju sastāva, gan Rīgas pilsētas nodarbinātības struktūras īpatnībām. Pirmajā gadījumā, runājot par migrantiem, kas pārceḷas no Rīgas uz piepilsētu, tie ir labāk situēti iedzīvotāji ar augstākiem vidējiem ienākumiem (Bērziņš 2011a). Tikmēr migranti no Latvijas perifērijas, kas ierodas aglomerācijas zonās, galvenokārt ir ar augstāko izglîtîbu tādēḷ, ka Rīgā dominējošāà nodarbinātība terciārajā sektorā vairāk piesaista augstākas izglīīības speciālistus, kamēr iedzīvotāji ar zemāku izglītību meklē primārā un sekundārā sektora darbības nozares ārzemēs. Abos gadījumos Rīgas piepilsētas teritorija dažādu iemeslu dēḷ piesaista iedzìvotājus ar augstāku izglītību. 


\section{Pateicība}

Raksts izstrādāts ar Valsts pētījumu programmas pētnieciskā projekta Nr. 5.2.4. "Sabiedrības atjaunošana, samazinot depopulācijas riskus, veicinot tautas ataudzi un saiknes ar diasporu" atbalstu.

\section{Atsauces}

Bērziṇš, M. (2011a). Iekšzemes migrācijas reǵionālās dimensijas Latvijā. Latvijas Zinātṇu Akadēmijas Vēstis (A dalı a), 65(3/4), 34-54.

Bērziņš, M. (2011b). Iedzīvotāju geogrāfiskās mobilitātes loma suburbanizācijas norisēs Latvijā: doktora darbs. Rīga. LU Ģeogrāfijas un zemes zinātņu fakultāte, Latvijas Universitāte.

Bērziņš, M. \& Krišjāne, Z. (2008). Amenity Migration in Postsocialist Metropolis: The Case of Rìga Agglomeration. In Proceedings of the Latvian Academy of Sciences. Section B. Natural, Exact, and Applied Sciences, 62(1-2), 71-77.

Burgmanis, G̣. (2014). Commuting Patterns in Riga Agglomeration: Evidence from a Survey Analysis of Youth. Regional Formation and Development Studies, 14(3), 16-29.

CSP (2018). Latvijas Republikas Centrālā statistikas pārvalde - Statistikas datubāzes. http://www.csb.gov.lv/ (20.1.2018)

Ivlevs, A. (2013). Minorities on the Move? Assessing Post-Enlargement Emigration Intentions of Latvia's Russian Speaking Minority. The Annals of Regional Science, 51(1), 33-52.

Krišjjāne, Z., Bērziņ̌š, M. (2012). Post-socialist Urban Trends: New Patterns and Motivations for Migration in the Suburban Areas of Rìga, Latvia. Urban Studies, 49(2), 289-306.

Krišjāne Z., Bērziñš M., Iṿ̣evs, A., Bauls, A. (2012). Who are the Typical Commuters in the Postsocialist Metropolis? The Case of Riga, Latvia. Cities, 29(5), 334-340.

Ourednicek, M. (2007). Differential Suburban Development in the Prague Urban Region. Geografiska Annaler, 89B(2), 111-126.

RAIM (2017). Reǵionālās attīstîbas indikatoru modelis - Vienkāršā RAIM rādītāju atlase. http://raim.gov.lv/lv/node/39 (20.01.2018)

RD PAD (2012). Rīgas domes Pilsētas attīstības departaments - Rīgas aglomerācijas robežu precizēšana. http://sus.lv/files/2012_Rigas_aglomeracijas_robezu_precizesana.pdf (10.11.2017)

Tammaru, T., Kulu, H. \& Kask, I. (2004). Urbanization, Suburbanization and Counter Urbanization in Estonia. Eurasian Geography and Economics, 45, 159-176.

Tammaru, T., van Ham, M., Leetmaa, K., Kahrik, A., Kamenik, K. (2011). Ethnic Dimension of Suburbanization in Estonia. Journal of Ethnic and Migration Studies, 39(5), 845-862.

\section{Summary}

Geographical mobility plays a significant role in forcing changes in population numbers. It also affects formation and composition of the population of Latvia. This research sheds light on how specific demographic characteristics of population composition affect the mobility behaviour of the external and internal zone of the Riga metropolitan area. Both zones have been chosen for research because suburbs can be considered as typical areas where the highest mobility and more intense changes in settlement structure and population composition are characteristic.

2011 Population Census data have been used to assess the connection between geographical mobility (mobile vs immobile residents) and the development of population composition, where demographic characteristics such as age, gender and education level are considered.

The main results of this research suggest that demographic characteristics are significant determinants of the mobility behaviour. Therefore, 1) males, 2) younger residents, 3) Latvians, and 4) those with the higher education, are more inclined to engage in the process of internal migration to the suburbs. 